\title{
A comparative study of application of multifunctional fertilizers based on amino acids and trace elements for winter wheat
}

\author{
Olga Shapowal* and Irina Mozharova \\ Institute of Agrochemistry named after D.N. Prianishnikov, 127550 Moscow, Russia
}

\begin{abstract}
The study of different complexes of new and innovative forms of fertilizers with the same ratio of trace elements applied in Nizhny Novgorod region in 2018 showed that the greatest grain yield increase to 0.45 and 0.435 t/ha or 7.8 and $7.4 \%$ was obtained using trace elements and amino acids in doses of 1.5 and $3.0 \mathrm{l} / \mathrm{ha}$. Similar results were observed when using amino acids in a dose of $2.0 \mathrm{l} / \mathrm{ha}$. The yield Increase was $0.44 \mathrm{t} / \mathrm{ha}$ compared to the control one of $2.59 \mathrm{t} / \mathrm{ha}$. In Ryazan region, the maximum yield was obtained using amino acids in a dose $1.0 \mathrm{l} / \mathrm{ha}$; the yield increase was $1.4 \mathrm{t} / \mathrm{ha}$ or $28.6 \%$, while the control yield was $4.9 \mathrm{t} / \mathrm{ha}$. Amino acid with microelements in a dose of 1.5 and 3.0 1/ha gave the high yield; the yield increase was $1 \mathrm{t} / \mathrm{ha}(20.4 \%)$.
\end{abstract}

\section{Introduction}

For new innovative fertilizers, multifunctionality is a prerequisite. The analysis of climate changes allows us to make a disappointing conclusion: more and more regions of the Russian Federation are risky farming zones. Requirements for new products such as cost reduction, the increasing adaptive potential of agrocenoses, productivity, product quality are becoming more relevant. The use of new technologies, including chemical substances, including multifunctional fertilizers with a set of macro, microelements, phytohormones, amino acids, humic and fulvic acids, is aimed at stabilizing growth processes and optimizing mineral nutrition [1-3].

For modern technologies, it is important to consider the plant as a complex self-regulating living system whose metabolism can be influenced by various multicomponent fertilizers. Stress loads caused by weather and endemic conditions violate metabolic processes, the energy and carbohydrate balance and change characteristics of growth, maturity and productivity, as well as deteriorate the non-specific immunity and resistance of plants to various diseases. One of the early stress effects on plants is the excessive accumulation of free radicals and the development of oxidative stress. Therefore, the use of complex fertilizers, taking into account mechanisms of selfregulation of photosynthesis, energy and carbohydrate metabolism, as well as mechanisms of antioxidant and antitoxic protection, becomes relevant.

Activating and stabilizing biochemical processes at an early stage of plant development increase the efficiency of further agrotechnical measures while reducing their number and saving the amount of funds used to feed and protect plants [4].
As recent studies show, amino acids are plant growth regulators [5] and an important component of the chelation of trace elements. This makes them one of the most promising ways to increase the multifunctionality of fertilizers. It is also necessary to emphasize that amino acids are one of the most active participants in plant metabolism, various biochemical processes, and the synthesis of protein and growth substances [6]. Their inclusion in the composition of water-soluble fertilizers containing micronutrients is a popular method of cultivating crops. They increase their effectiveness in critical periods of development, when the demand for micronutrients is high [7-10].

The dynamics of inclusion of these fertilizers in the "State catalog of pesticides and agrochemicals approved for the application in the Russian Federation" indicates an increased interest in their application. More than 50 names of similar products have been registered registered. However, the comparative assessment of the effectiveness of different forms of multifunctional fertilizers based on amino acids and trace elements, including those with chelate compounds of trace elements, require a more thorough and scientific approach.

For this purpose, in 2018, the All-Russian Research Institute of Agricultural Chemistry named after D.N. Pryanishnikov conducted comparative studies on different forms of fertilizers based on amino acids and trace elements, including mineral salts of trace elements. The optimal doses of fertilizers were identified and scientifically substantiated during laboratory, screening and model experiments. To comply with the principle of the only difference, complexes were selected: a chelated complex of trace elements based on EDTA, a complex based on trace elements with amino acids. 


\section{Materials and methods}

In the small-plot experiment conducted in 2018, studies were carried out in the conditions of Nizhny Novgorod region on winter wheat Moscovskaya 39 and in Ryazan region on winter wheat Viola.

In Nizhny Novgorod Region, the soil of the experimental plot was light gray forest loamy, had a low content of organic matter (1.6\%), an average content of mobile potassium $(108 \mathrm{mg} / \mathrm{kg})$ and a high content of mobile phosphorus $(231 \mathrm{mg} / \mathrm{kg})$. The soil was characterized by a strongly acidic reaction of the soil medium (4.2 $\mathrm{pH}$ units), an average degree of base saturation $(67 \%)$ and absorbed bases $(13.2 \mathrm{mEq} / 100 \mathrm{~g})$.

In Ryazan region, the soil was gray forest heavy loamy. The agrochemical soil analysis showed that the humus content was $4.66 \%$. The content of phosphorus $\left(\mathrm{P}_{2} \mathrm{O}_{5}\right)$ and potassium $\left(\mathrm{K}_{2} \mathrm{O}\right)$ was respectively $223 \mathrm{mg} / \mathrm{kg}$ and $184 \mathrm{mg} / \mathrm{kg}$. The trace mineral content ranged from $(22.79 \mathrm{mg} / \mathrm{kg}$ to $8.4 \mathrm{mg} / \mathrm{kg}$, the zinc content was $1.61 \mathrm{mg} / \mathrm{kg}$ and the boron content was average. The reaction was 6.22 .

The experiment scheme: 1. Control - NPK background (Background); 2. Background + chelate microelements: foliar application in the tilleringshooting phases, in the flowering earing phases (boretanolamine $-8.8 \mathrm{~g}+$ zinc chelate $-75.3 \mathrm{~g}+$ manganese chelate $-57.7 \mathrm{~g}+$ copper chelate $-10 \mathrm{~g}+$ ammonium molybdate $-0.6 \mathrm{~g}$ )/ha (Background + CME, a single dose); 3 . Background + chelate microelements: foliar application in the tillering and shooting phases, in the flowering and earing phases (boretanolamine $17.6 \mathrm{~g}+$ zinc chelate $-150.6 \mathrm{~g}+$ manganese chelate $115.4 \mathrm{~g}+$ copper chelate $-20 \mathrm{~g}+$ ammonium molybdate $1.2 \mathrm{~g}$ )/ha (Background + CME, a double dose); 4. Background + amino acids with microelements: foliar application in the tillering -shooting phases, in the flowering earing phases in a dose of $1.5 \mathrm{l} / \mathrm{ha}$ (Background $+\mathrm{M}+\mathrm{ME}, 1.5 \mathrm{l} / \mathrm{ha}$ ); 5. Background + amino acids with microelements: foliar application in the tillering-shooting phases, in the flowering earing phases in a dose of 3 1/ha (Background + AM + ME, 3 1/ha); 6. Background + amino acids: foliar application in the tillering -shooting phases, in the flowering earing phases in a dose of 1 1/ha (Background + AM, 1 1/ha); 7. Background + amino acids: foliar application in the tillering -shooting phases, in the flowering earing phases in a dose of 2 1/ha (Background + AM, 2 1/ha).

To comply with the principle of the only difference, the following complexes were selected: a chelated complex of trace elements based on EDTA, a complex based on trace elements with amino acids. The complexes included the same set with a single ratio of trace elements:

- a complex of chelate microelement (boretanolamine $(\mathrm{B}-17 \%)-6 \%+$ zinc chelate $(\mathrm{Zn}-$ $15 \%)-49 \%+$ manganese chelate $(\mathrm{Mn}-13 \%)-38 \%$ + copper chelate $(\mathrm{Cu}-15 \%)-6.6 \%+$ ammonium molybdate $(\mathrm{Mo}-52 \%)-0.4 \%$;

- a complex of trace elements with amino acids (organic matter $-40 \%$, amino acids $-10 \%$, including free amino acids $-8 \%$, total nitrogen $(\mathrm{N})-5 \%$, zinc
$(\mathrm{Zn})-0.75 \%$, manganese $(\mathrm{Mn})-0.5 \%$, boron $(\mathrm{B})-$ $0.1 \%$, copper $(\mathrm{Cu})-0.1 \%$, molybdenum (Mo) $0.02 \%)$;

- amino acids (organic matter $-60.0 \%$, nitrogen (N) $-7 \%$, amino acids $-14.4 \%$, including free amino acids $-12 \%$ ).

The area of the plot was 100 square meters, 4-fold repetition.

Field experiments were conducted according to the generally accepted methods and relevant state standards:

The soil analysis was carried out according to the generally accepted methods:

- organic matter - according to GOST 26213-91;

- exchange acidity ( $\mathrm{pH}$ of salt extract) - according to GOST 26483-85;

- content of mobile phosphorus - according to GOST R54650-2011;

- content of mobile potassium - according to GOST R 54650-2011;

- hydrolytic acidity - according to GOST 26212-91;

- the number of absorbed bases - according to GOST 27821-88;

- the degree of soil saturation with the bases - by the calculation method.

- phenological observations, identification of density of seedlings, the crop structure were carried out according to the method of the State crops variety testing (1989) and the Guide for conducting registration tests on plant growth regulators, defoliants and desiccants (2016);

- the crop structure was determined in 10 plants, the total and productive bushiness, the number of grains in the ear, the mass of 1000 grains were determined according to GOST 12042-80;

- density of plants before harvesting was determined by counting them according to the method of the State crop variety testing (1989);

- the percentage of dry matter, nitrogen - according to GOST 13496.4-93; protein content in grain - by multiplying the total nitrogen content by 5.7 [11];

- the weight of 1000 grains - according to GOST 12042-80;

- gluten content - according to GOST 3040-55 and 9404-60;

- the yield was determined by continuous threshing of the entire mass from the accounting plot. The accounting data was reduced to $100 \%$ purity and $14 \%$ humidity according to GOST 27548-97.

The research results were processed by the methods of variance and correlation-regression analyzes [12]. Statistical processing was carried out in AGROS 2.06.

\section{Results}

In 2017-2018, weather conditions for the autumn-winter months in Nizhny Novgorod region ensured good preservation of winter wheat by the beginning of the growing season. Favorable summer weather conditions ensured early ripening. The number of plants that died during the growing season was insignificant; by the time 
of harvesting, their number was $391-460 \mathrm{pcs} / \mathrm{m}^{2}$, safety of winter wheat plants was 65-77\%.

An analysis of the crop structure showed that foliar application using chelated trace elements and amino acid-based fertilizers did not affect the total and productive bushiness of winter wheat. The number of total stems varied from 710 to $897 \mathrm{pcs} / \mathrm{m}^{2}$, productive stems - from 637 to $824 \mathrm{pcs} . / \mathrm{m}^{2}$, the total tillering coefficient was 1.9-2.2, the productive tillering coefficient was 1.6-2.0. The height did not depend on the application of the fertilizers. The plants were uniform, their height was $79.2-85.3 \mathrm{~cm}$. The spike parameters determining the yield were uniform.

According to the experimental variants, the spike length varied from 5.7 to $6.5 \mathrm{~cm}$, the number of spikelets was 14.0-15.3, the number of grains in the spike was 28.5-33.5. The mass of grain was $1.3-1.6 \mathrm{~g}$, and the mass of straw was $2.3-2.6 \mathrm{~g}$. The ratio of the mass of grain to the mass of straw was 1:1.6-1:1.8. In some variants, a substantial increase in the mass of 1000 grains was observed. A reliable increase of $3.4 \mathrm{~g}$ was achieved by foliar fertilizing with a double dose of fertilizers containing chelated trace elements. A significant increase in the mass of 1000 grains was achieved by foliar fertilizing with amino acids and microelements.

In the control option, the grain yield was $2.59 \mathrm{t} / \mathrm{ha}$ (Table 1). In the experimental options, the yield increased by $0.19-0.46 \mathrm{t} / \mathrm{ha}$. In options where a substantial increase in the mass of 1000 grains was observed, an increase in the yield was significant. In case of foliar fertilizing with a double dose of a complex containing chelated trace elements, the yield increase was $0.42 \mathrm{t} / \mathrm{ha}(16.2 \%)$. The complex of amino acids with microelements in single and double doses contributed to an increase in the grain yield by 0.45 and $0.46 \mathrm{t} / \mathrm{ha}(17.4$ and $17.8 \%)$, respectively. A double-dose amino acid complex increased the yield by $0.44 \mathrm{t} / \mathrm{ha}$ (17\%).

The content of crude gluten was high $-33-35 \%$. The maximum content was achieved due to the foliar application (chelate trace elements and amino acids in a dose of $2.0 \mathrm{l} / \mathrm{ha}$ ). The IDK indicator was $78-87$ units.

Table 1. Crops yield and grain quality of winter wheat Moskovskaya 39 (Nizhny Novgorod region, 2018)

\begin{tabular}{|c|c|c|c|c|}
\hline Options & $\begin{array}{l}\text { Yield, } \\
\text { t/ha }\end{array}$ & Gluten content, $\%$ & IDK & $\begin{array}{c}\text { Protein content, } \\
\%\end{array}$ \\
\hline 1. NPK & 2.59 & 33 & 87 & 17.4 \\
\hline 2. Background + CME complex, single dose & 2.81 & 34 & 84 & 17.5 \\
\hline 3. Background + CME complex, double dose & 3.01 & 35 & 82 & 17.6 \\
\hline 4. Background + complex AM + ME, 1.5 1/ha & 3.05 & 34 & 80 & 17.6 \\
\hline 5. Background + complex AM + ME, 3.0 1/ha & 3.04 & 34 & 78 & 17.7 \\
\hline 6. Background + AM complex, 1. 0 l/ha & 2.78 & 33 & 78 & 17.8 \\
\hline 7. Background + AM complex, 2.0 1/ha & 3.03 & 35 & 78 & 17.9 \\
\hline $\mathrm{LSD}_{05}$ & 0.37 & & & \\
\hline
\end{tabular}

Under the prevailing weather conditions of 2018 in Ryazan Region, two-fold foliar ferilizing of winter wheat Viola with different complexes contributed to an increase in the number of productive stems by $22-25 \%$ when using chelate microelements, by 30-34\% - when using amino acids with trace elements and 32-45\% when using amino acids.

Foliar ferilizing positively affected the length of the main spike; it was $8.1 \mathrm{~cm}$ in the control option but increased by $0.7 \mathrm{~cm}$ when using chelated microelements; by $0.8-0.9 \mathrm{~cm}-$ when using amino acids with micronutrients, by $0.7-1 \mathrm{~cm}-$ when using amino acids.

The number of spikelets also increased wwhen using chelkated microelements (14.6-15.0 pcs). When using a complex of amino acids with trace elements, it was 15.6 pcs; when using amino acids, it was $15.1-15.8$ pcs., against the control number of 14.8 pcs. An increase in the number of spikelets in caused an increase in the number of grains (32.3 pcs) and the mass of grain per ear (up to $1.75-1.85 \mathrm{~g}$ ), whereas in the control option, the number of grain was 30.4 pcs. with a grain mass of $1.67 \mathrm{~g}$. Foliar application of amino acids with trace elements in doses of 1.5 and $3 \mathrm{l} / \mathrm{ha}$ and amino acids in a dose of 1 l/ha infleunced the grain development. Minimum indicators of the number of grains in the ear and the mass of grain were observed when using chelated trace elements in maximum doses.

Table 2. Crops yield and grain quality of winter wheat Viola (Ryazan region, 2018)

\begin{tabular}{|c|c|c|c|c|}
\hline Options & Yield, t/ha & Gluten content, \% & IDK & Protein content, $\%$ \\
\hline 1. NPK & 4.9 & 21,3 & 67 & 11.6 \\
\hline 2. Background + CME complex, single dose & 5.9 & 21.9 & 68 & 11.6 \\
\hline 3. Background + CME complex, double dose & 4.8 & 21.8 & 66 & 11.7 \\
\hline 4. Background + complex AM + ME, $1.5 \mathrm{l} / \mathrm{ha}$ & 5.9 & 20.9 & 70 & 11.5 \\
\hline Background + complex AM + ME, 3.0 l/ha & 5.9 & 21.7 & 67 & 11.6 \\
\hline 6. Background + AM complex, 1. 0 l/ha & 6.3 & 21.8 & 69 & 11.4 \\
\hline 7. Background + AM complex, 2.0 l/ha & 5.5 & 22.3 & 69 & 11.5 \\
\hline $\mathrm{LSD}_{05}$ & 0.16 & & & \\
\hline
\end{tabular}


Under the action of foliar fertilizers, the highest yield of $6.3 \mathrm{t} / \mathrm{ha}$ was obtained using amino acids in the minimum dose (1 1/ha); without foliar fertilzing, it was $4.9 \mathrm{t} / \mathrm{ha}$. An increase in the fertilizer consumption rate to 2 1/ha had a lesser effect. The grain yield increase was $0.6 \mathrm{t} / \mathrm{ha}$ or $12 \%$. The use of amino acids with microelements in single and double doses provided the same result (chelated microelements in a single dose). Wheat yield increased by 1 t/ha or $20 \%$. A double increase in the dose of chelated microelements under high temperatures and low humidity had a depressing effect on the yield which remained at the level of the control option and amounted to $4.8 \mathrm{t} /$ ha (Table 2).

When cultivating wheat, it is important to obtain a stable crop and ensure appropriate grain quality.

Gluten content was highest when using amino acids in a dose of $2.01 /$ ha $-22.3 \%$, exceeding the control one by $1.0 \%$. Protein content and the IDK remained at the level of control ones.

\section{Discussion}

The results of studies in Nizhny Novgorod region showed that crop development was influenced by characteristics of the variety, weather conditions, which determined the intensive growth of the vegetative mass at the beginning of the growing season, due to increased moisture and good heat supply in the winter-spring period.

As a result of foliar fertilizing with a complex of amino acids with microelements in doses of 1.5 and $3.0 \mathrm{l} / \mathrm{ha}$, the yield was 3.04-3.05 t/ha which exceeded the control yield by $0.45-0.46$ t/ha $(17.4-17.8 \%)$. Despite minor changes in the elements of the crop structure, the use of amino acids in a maximum dose of $2.0 \mathrm{l} / \mathrm{ha}$ increased the yield.

The use of fertilizers affected the size of the crop and improved baking qualities of grain and its nutritional value.

Gluten content was low. The amount of protein was high and varied from 16.4 in the control option to $17.5-17.9 \%$ in the options with fertilizers. The maximum content of $17.9 \%$ was obtained using amino acids in a dose of $2.0 \mathrm{l} / \mathrm{ha}$.

The preliminary data showed a tendency to increase the resorption of trace elements in wheat grain using a complex of amino acids and trace elements in a dose of $3.0 \mathrm{l} / \mathrm{ha}$. Zinc content increased by $7.5 \%$, manganese by $4.3 \%$, and copper - by $13.3 \%$.

In Ryazan region, in 2017-2018, the weather conditions were favorable for the winter wheat. There were $594.6 \mathrm{~mm}$ of precipitation which is $5.6 \mathrm{~mm}$ higher than the mean annual values. Precipitation was uneven, the bulk of them was in October, November, December, and April. The air temperature was high indicators; it was higher than the average one by $4.6^{\circ} \mathrm{C}$.

The studies showed that when applying different forms of micronutrient fertilizers for foliar fertilizing an equivalent yield increase was obtained using a double dose of chelated trace elements, a complex of amino acids and trace elements in a dose 1.5 1/ha and amino acids in a dose of $21 /$ ha. These data confirm the results of registration tests on winter and spring wheat conducted in 2016-2017. The research is continuing in 2019.

\section{Conclusion}

Comparative experiments on the small plots in Nizhny Novgorod region showed that the highest yield was obtained using a complex of trace elements and amino acids in a dose of 1.5 and $3.0 \mathrm{l} / \mathrm{ha}-3.05$ and $3.04 \mathrm{t} / \mathrm{ha}$. The yield increase was 0.45 and $0.435 \mathrm{t} / \mathrm{ha}$, respectively, or 7.8 and $7.4 \%$. The same effect was obtained using amino acids in a dose of $2.0 \mathrm{l} / \mathrm{ha}$. The yield was $3.03 \mathrm{t} / \mathrm{ha}$ while the control one was $2.59 \mathrm{t} / \mathrm{ha}$. In Ryazan region, the maximum efficiency was shown by a complex of amino acids in a dose of $1.0 \mathrm{l} / \mathrm{ha}$, the yield increase was $1.4 \mathrm{t} / \mathrm{ha}$ or $28.6 \%$, while the control yield was $4.9 \mathrm{t} / \mathrm{ha}$. A complex of amino acids with microelements in a dose of 1.5 and $3.0 \mathrm{l} / \mathrm{ha}$ was effective. The yield increase for both doses was $1 \mathrm{t} / \mathrm{ha}(20.4 \%)$.

\section{References}

1. L. Jannin, M. Arkoun, P. Etienne, P. Laine, D. Goux, M. Garnica, M. Fuentes, S. San Francisco et al., Brassica napus Growth is promoted by Ascophyllum nodosum (L.)Le Jol. Seaweed Extract: Microarray Analysis and Physiological Characterization of $N, C$, and $S$ Metabolisms, J. of Plant Growth Regulati., Stringer., 32(1), 31-52 (2013)

2. W. Bergmann, ed., Nutritional disorders of plants: Development, visual and analytical diagnosis (Fischer, Jena; Stuttgart; New York, 1992)

3. S.B. Erlykov, A.N. Nekhoroshee, M.I. Ivanova, D.I. Engalychev, Russian amino chelate fertilizers of the Agrovin series on white cabbage, Bull. of Mari State Univer. Ser. Agricult. Sci., Econ. Sci., Z(2(10)) (Yoshkar-Ola, 2017)

4. L.V. Osipova, I.V. Vernichenko, I.A. Bykovskaya, P.A. Yakovlev, The effect of selenium and zinc on the drought tolerance of plants of barley varieties and their ability to normalize nitrogen nutrition after a drought (experiments with 15N), Agricult. Chem., 3, 43-55 (2015)

5. Amino acid stimulants, Retrieved from: https://studbooks.net/76234/agropromyshlennost/am inokislotnye_stimulyatory

6. Intedhar Abbas Marhoon, Majeed Kadhim Abbas, Effect of foliar application of seaweed extract and amino acids on some vegetative and anatomical characters of two sweet pepper (Capsicum Annuum L.) cultivars, Int. J. of Res. Studies in Agricult. Sci. (IJRSAS), 1(1), 35-44 (2015)

7. Yu.A. Krutyakov, A.A. Kudrinsky, A.A. Gusev et al., Synthesis of positively charged hybrid PHMBstabilized silver nanoparticles: the search for a new 
type of active substances used in plant protection products (IOP Publishing Ltd, 2017)

8. Amino acids for crops feeding, Retrieved from: http://www.agroperspectiva.com.ua/ru/aminokisloty -dlja-podkormki-urozhaja/

9. Leaf feeding, Retrieved from: http://amtsibir.ru/listovye-podkormki/
10. A.I. Zavrazhnova, ed., Modern problems of science and production in agricultural engineering (Lan, St. Petersburg, 2013)

11. A.S. Radov, I.V. Pustovoy, A.V. Korolkov et al, Workshop on agrochemistry, 4rd ed. (Agropromizdat, Moscow, 1985)

12. B.A Dospekhov, The methodology of field experiments (with the basics of statistical processing of research results) (Alliance, Moscow, 2011) 